\title{
Protective Effect of Ipomoea batatas L Leaves Extract on Histology of Pancreatic Langerhans Islet and Beta Cell Insulin Expression of Rats Induced by Streptozotocin
}

\author{
Dody Novrial ${ }^{1 *}$, Soebowo², Parno Widjojo ${ }^{3}$ \\ 'Department of Anatomical Pathology, Faculty of Medicine, Jenderal Soedirman University, Purwokerto, \\ Indonesia \\ ${ }^{2}$ Department of Anatomical Pathology, Faculty of Medicine, Diponegoro University, Semarang, Indonesia \\ ${ }^{3}$ Department of Pharmacology, Faculty of Medicine, Diponegoro University, Semarang, Indonesia
}

*Corresponding author email: dodynovrial@unsoed.ac.id

Received August 06, 2019; Accepted February 17, 2020; Available online March 15, 2020

\begin{abstract}
Sweet potato (Ipomoea batatas L) leaf is one of the well-known vegetables among Indonesian. It is also often used as traditional medicine for diabetes mellitus. This research aimed to investigate the protective effect of $I$. batatas $L$ leaves extract on the pancreas of type 1 diabetes animal model. Twenty-five male Sprague-Dawley rats were divided into 3 treatment groups and 2 control groups. Streptozotocin (STZ) was injected low doses $(40 \mathrm{mg} / \mathrm{kg} \mathrm{BW})$ intraperitoneally for 5 consecutive days, I. batatas L leaves extract (doses $0.25,0.8$, and $2.5 \mathrm{~g} / \mathrm{kg} \mathrm{BW}$ ) were administered for 14 days after the first STZ injection. Fasting blood glucose was analyzed after complete STZ induction (day 6) and after 14 days of treatment. At the end of the study, rats were killed, and pancreas tissues were removed for histological examination and immunohistochemical procedures using anti-insulin antibody. Diabetic rats treated with $2.5 \mathrm{~g} / \mathrm{kg} \mathrm{BW} \mathrm{I.} \mathrm{batatas} \mathrm{L} \mathrm{leaves}$ extract showed the lowest fasting blood glucose among treatment groups and had approximately $50 \%$ normal Langerhans islets with functional beta cells. These results suggest that $I$. batatas $L$ leave extract has anti-diabetic activity through its protective effect on the pancreas.
\end{abstract}

Keywords: Sweet potato, IDDM, type 1 diabetes, insulitis, beta-cell immunohistochemistry.

\section{INTRODUCTION}

Blood glucose homeostasis is controlled by pancreatic endocrine beta cells found in the Langerhans islands. The optimal control of blood glucose level depends on the production and secretion of insulin by pancreatic beta cells. The failure of pancreatic beta-cell adaptation against changes in the body, such as weight gain, pregnancy, peripheral insulin sensitivity, or tissue damage, may cause a chronic increase of blood glucose known as diabetes (Weir \& Bonner-Weir, 2013).

Diabetes is a major endocrine disorder that is reported to increase rapidly in the world. Based on the World Health Organization (WHO) and American Diabetes Association (ADA) diagnostic criteria, in 2030, there will be 439 million people affected by the disease (Shaw, Sicree, \& Zimmet, 2010). This became one of the focus attention on health strategies both in the national and international scale. One strategic effort developed is the utilization of traditional medicinal plants for diabetes as recommended by WHO (liaola et al., 2014).

Several studies have shown the beneficial effect of Ipomoea batatas L (sweet potato) leaves extract as an antidiabetic herb. I. batatas L leaf is one of the popular vegetables consumed by people in
Southeast Asia, especially Indonesia. I. batatas leaves are rich in nutrients, fibers, vitamins, minerals, and polyphenol as an antioxidant agent (Sun, Mu, $X i$, Zhang, \& Chen, 2014). Aqueous extract of $I$. batatas leaf could control blood glucose and improve kidney and blood hematological functions (Rafiu \& Luka, 2018). Ethyl acetate extract fraction of $I$. batatas leaves could stimulate insulin secretion and inhibited glucogenesis enzymatic activity in streptozotocin (STZ) induced diabetic mice (Lien et al., 2011).

STZ is one of the chemicals which widely used to induce diabetes in experimental animals. It is a genotoxic methylating agent that selectively destroy pancreatic beta cells and initiate insulin-dependent diabetes mellitus (IDDM) or type 1 diabetes (T1D) (Wu \& Yan, 2015). T1D is an autoimmune disease defined by the infiltration of mononuclear cells into Langerhans islet (insulitis) and decreases numbers of pancreatic beta cells (Kawasaki, 2014). This study aimed to investigate the protective effect of I. batatas leaves extract on the pancreas of the TID animal model. We analyzed histology of Langerhans islets, and beta-cell insulin expression of streptozotocin (STZ) induced diabetic rats by immunohistochemistry procedures. 


\section{EXPERIMENTAL SECTION \\ Plant Material}

Fresh leaves of I. batatas (family of clones B 0059 3) were harvested in July from the Bandungan plantation area in Central Java Indonesia. They were washed thoroughly in water until clean and free from the debris. The leaves were drained and oven-dried at $45^{\circ} \mathrm{C}$ for 48 hours, then pollinated with a $1 \mathrm{~mm}$ diameter holes pollinator to get about $600 \mathrm{~g}$ leaves powder. The extraction was performed in The Institute for Integrated Research and Testing Gadjah Mada University Yogyakarta using the percolation method. Leaves powder was put into the percolator, added $3 \mathrm{~L}$ technical petroleum ether, allowed to stand for 24 hours, and then dripped 3-4 drops per second until the filtrate clear in color. The pulp was oven-dried at $50^{\circ} \mathrm{C}$ for 24 hours. Dried pulp was soaked in $2.5 \mathrm{~L}$ $70 \%$ ethanol, stirred for 30 minutes, allowed to stand for 24 hours, and then filtered. The filtrate then evaporated and concentrated in an oven at $50^{\circ} \mathrm{C}$. The obtained I. batatas leave extract was dissolved in aqua dest and administered at $0.25,0.8$, and $2.5 \mathrm{~g} / \mathrm{kg}$ BW/day orally.

\section{Animals}

Twenty-five male Sprague-Dawley rats, aged 2-3 months, $180-200 \mathrm{~g}$, were obtained from Animal Laboratory of The Institute for Integrated Research and Testing Gadjah Mada University Yogyakarta. They were caged individually and maintained in a wellventilated room with a temperature of $25^{\circ} \mathrm{C}$ and 12 hours light and dark cycle. Standard rat feed from the laboratory (AD II consisted of 15\% protein, 7\% fat, $6 \%$ rough fibers, and various minerals) and aqua dest were given as daily consumption ad libitum. Rats were aclimatised for a week, then divided into five experimental groups: 1. Normal control group, 2. Diabetic group non treated, 3. The diabetic group treated with $0.25 \mathrm{~g} / \mathrm{kg} \mathrm{BW} \mathrm{I.} \mathrm{batatas} \mathrm{leaves} \mathrm{extract}$ daily, 4. The diabetic group treated with $0.8 \mathrm{~g} / \mathrm{kg}$ BW I. batatas leaves extract daily, and 5. The diabetic group treated with $2.5 \mathrm{~g} / \mathrm{kg}$ BW I. batatas leaves extract daily. The extract was given continuously for 14 days after the first STZ induction. Control and the diabetic not treated group were given the only saline. This study was approved by the Health Research Ethics Committee Faculty of Medicine Diponegoro University/ Dr. Kariadi Hospital Semarang.

\section{Induction of Diabetes}

Streptozotocin (Cat.\#572201 CALBIOCHEM ${ }^{\circledR}$ ) was used to induce pancreatic Langerhans islets and beta cells damage. STZ in citrate buffer $(\mathrm{pH} \mathrm{4.5)}$ was injected at multiple low doses $(40 \mathrm{mg} / \mathrm{kg}$ BW) intraperitoneal daily for 5 consecutive days. Fasting blood glucose of all rats at day 6 (24 hours after the last STZ injection to confirm diabetes status), and at the end of the study were analyzed using sphectrophotometer (UV-1800 Shimadzu). Fasting blood glucose greater than $200 \mathrm{mg} / \mathrm{dl}$ was considered as diabetes (Pournaghi, Sadrkhanlou, Hasanzadeh, \& Foroughi, 2012).

\section{Histological Examination of The Pancreas}

Pancreas tissues were fixed in buffered formalin and then embedded in paraffin. Sections $(4 \mu \mathrm{m})$ from the paraffin blocks were prepared and stained with hematoxylin and eosin (H\&E) procedure. Histological examination of pancreas performed by evaluating the degree of insulitis on Langerhans islets at 400x magnification, consistent across 10 fields of view. Insulitis were graded as follows: $0=$ intact islets; $1=$ mild insulitis, if infiltration of mononuclear cells $(\mathrm{MNC})<25 \%$ of islets; $2=$ moderate insulitis, if $25 \%$ $50 \%$ of islets were infiltrated by MNC; $3=$ severe insulitis, if infiltration of MNC > 50\% of islets; and 4 $=$ end-stage islet, if all the islets were necrotic (complete loss of beta cell).

Immunohistochemistry of Beta Cells Insulin Expression

Formalin-fixed paraffin-embedded (FPPE) tissue blocks were cut into $4 \mu \mathrm{m}$ thick sections and mounted on a slide coated with poly-L-lysine. The slides then followed procedures of dewaxing, rehydration, blocking with hydrogen peroxide, and antigen retrieval with a microwave. Slides were incubated with primary antibody anti-insulin Ab-5 (Clone INS05) for 30 minutes at room temperature. Incubation with secondary antibody and product visualization (Dako) was performed with diaminobenzidine substrate as the chromogen. The slides were finally counterstained with hematoxylin and washed once each with distilled water and PBS. Assessment of insulin expression of beta cells performed using Allred score at 400x magnification, consistent across 10 fields of view (Allred, Harvey, Berardo, \& Clark, 1998).

\section{Statistical Analysis}

One-way ANOVA followed by LSD post hoc test was performed for blood glucose analysis. The degree of insulitis and insulin expression of beta cells were analyzed using the Kruskal-Wallis test followed by Mann-Whitney $U$ test. A p-value $<0.05$ was considered significant.

\section{RESULTS AND DISCUSSION \\ Fasting Blood Glucose}

Table 1 showed the potential effect of STZ to induce diabetic animal models and the protective effect of $I$. batatas leaves extract. Multiple low doses of STZ injected intraperitoneal in 5 consecutive days could increase fasting blood glucose level 6 times higher than the normal group. Diabetic rat treated with $I$. batatas leaves extract showed lower fasting blood glucose levels than the untreated one. Diabetic rats treated with $2.5 \mathrm{~g} / \mathrm{kg}$ BW extract had significantly lowest fasting blood glucose levels $(p<0.05)$ both after complete STZ induction (day 6) and at the end of the experiment (day 14). Post hoc analysis of the latest fasting blood glucose demonstrated significant differences between each group $(p<0.05)$. 
Table 1. Effect of Ipomoea batatas $L$ leaves extract on blood fasting glucose

\begin{tabular}{llll}
\hline \multicolumn{1}{c}{ Groups } & $\begin{array}{l}\text { Blood Glucose } \\
\text { Day-6 }(\mathrm{mg} / \mathrm{dl})\end{array}$ & $\begin{array}{l}\text { Blood Glucose } \\
\text { Day-14 }(\mathrm{mg} / \mathrm{dl})\end{array}$ & $\begin{array}{l}\text { Changes in } \\
\text { Glucose }(\%)\end{array}$ \\
\hline Normal rat & $83.42 \pm 11.11^{*}$ & $86.58 \pm 4.23^{*}$ & 3.79 Up \\
Diabetic rat untreated & $490,56 \pm 36.33$ & $484.72 \pm 16.29$ & 1.19 Down \\
Diabetic rat $+0.25 \mathrm{~g} / \mathrm{kgBW}$ extract & $436,92 \pm 77.05$ & $375.32 \pm 23.93^{*}$ & 14.09 Down \\
Diabetic rat $+0.8 \mathrm{~g} / \mathrm{kgBW}$ extract & $473,44 \pm 28.69$ & $226.56 \pm 7.16^{*}$ & 52.15 Down \\
Diabetic rat $+2.5 \mathrm{~g} / \mathrm{kgBW}$ extract & $419,58 \pm 49.39^{*}$ & $179.46 \pm 6.79^{*}$ & 57.23 Down \\
\hline
\end{tabular}

$: p<0.05$ vs diabetic rat untreated group

TID is an autoimmune disease characterized by a local islet inflammatory reaction followed by the destruction of insulin-secreting beta cells (Tyka et al., 2019). Previous studies proved that type 1 diabetes is an organ-specific disease caused by an autoimmune reaction against pancreatic beta cells (Kawasaki, 2014). In experimental pathology, STZ is a widely used chemical to induce TID model in rodents. It is a broad-spectrum antibiotic obtained from Streptomyces acromogenes (Rosol, DeLellis, Harvey, \& Sutcliffe, 2013). STZ contains glucose molecules which bind to the high methyl nitrosourea moiety which directs it to pancreatic beta cells. It can recognize glucose transporter 2 (GLUT2) receptor in the beta-cell plasma membrane, and therefore pancreatic beta-cells become specific target of STZ (Wu \& Yan, 2015).

Multiple low doses of STZ (MLDS) is commonly used to induce TID model which has clinical, histological, and immunological features similar to those of the human disease (Martin et al., 2007). The diabetogenic effect of MLDS $(40 \mathrm{mg} / \mathrm{kg}$ BW for 5 consecutive days intraperitoneal) is initiated by reactive oxygen species (ROS) through a direct toxic effect on GLUT2, stimulation of dependent T cells, and activation of IKK- $\alpha$ and NF-KB (Goud, Dwarakanath, \& Swamy, 2015; Wu \& Yan, 2015). DNA alkylation in pancreatic beta cells occurred 45 minutes after MLDS injection, then mononuclear cells will infiltrate the islets and start the immunologic reaction that will lead to beta-cell destruction and diabetes (Martin et al., 2007; Thulesen, Cathrine, Jensd, \& Steel, 1997).

In this study, we administered the rats with $I$. batatas leaves extract quickly after the first STZ injection in order to observe its protective effect. Our result demonstrated that administration of $I$. batatas leaves extract for 14 days along with MLDS induction could maintain normal blood glucose levels of rats in a dose-dependent manner. Blood glucose level decreased as much as $14.09 \%, 52.15 \%$, and $57.23 \%$ in the group treated with $0.25 \mathrm{~g} / \mathrm{kg} \mathrm{BW}, 0.8 \mathrm{~g} / \mathrm{kg} \mathrm{BW}$, and $2.5 \mathrm{~g} / \mathrm{kg} \mathrm{BW}$ extract respectively.

Several studies have reported the beneficial effects of $I$. batatas in the prevention and treatment of chronic diseases (Ayeleso, Ramachela, \& Mukwevho, 2016). I batatas leaves contain bioactive compounds that have antioxidant, anti-inflammatory, anti-tumor, and immunomodulatory activities (Ayeleso et al., 2016; Koncic, Petlevski, \& Kalođera, 2013; Mbayei-Nwaoha
\& Emejulu, 2013). Both immunomodulatory and antioxidant properties of I batatas leaves extract might play an important role in removing oxidative damage caused by STZ induction (Niwa, Tajiri, \& Higashino, 2011).

Two major phytochemicals found in I batatas leaves are flavonoid and phenolic content. The previous study of I batatas leaves variants in Malaysia showed flavonoid content ranged between $96 \mu \mathrm{g}$ and $263.5 \mu \mathrm{g} / \mathrm{g}$ dry weight, meanwhile, total phenolic contents ranged from 2.78 to $5.35 \mathrm{~g} / 100 \mathrm{~g}$ dry weight (Hue, Boyce, \& Somasundram, 2012). Recently, anthocyanins, catechins, flavonols (quercetin), and proanthocyanidins have been identified as flavonoid contents in I batatas leaves extract (Carvalho, Cavaco, Carvalho, \& Duque, 2010), and caffeic acid as an active compound of the phenol group (Majid et al., 2018).

Flavonoids become the main bioactive compound obtained from I. batatas leaves extract (MbayeiNwaoha \& Emejulu, 2013). Flavonoids have pharmacological property as a potent antioxidant that plays a role in the amelioration of diabetes status (Sarian et al., 2017). Furthermore, flavonoids could stimulate glucose uptake in peripheral tissue, and act as insulin secretagogues by influencing the pleiotropic mechanisms of insulin signaling (Cazarolli et al., 2008; Soares, Leal, Silva, Almeida, \& Oliveira, 2017). Quercetin and catechin involve the modulation of $\mathrm{Ca}^{2+}$ by alterations in $\mathrm{Ca}^{2+}$ fluxes. The increase in calcium concentration intracellular stimulates many cellular pathways that promote insulin secretion (Soares et al., 2017). In addition, quercetin can enhance glucose uptake in peripheral tissue and reduce insulin resistance (Rafiu \& Luka, 2018).

Meanwhile, I batatas leave extract also has abundant phenolic compounds such as caffeic acid and its derivatives (Ghasemzadeh, Omidvar, \& Jaafar, 2012; Niwa et al., 2011). Caffeic acid is known as a potent inhibitor of mitogenic activity which induces $T$ cell proliferation, lymphokine production, and activation of NFkB (Majid et al., 2018; Sidoryk, Jaromin, Filipczak, Cmoch, \& Cybulski, 2018). Caffeic acid and its derivatives also strongly inhibit the production of COX-2 and iNOS (Choi, Tran, Lee, Min, \& Kim, 2018). These anti-inflammatory effects of caffeic acid and insulin-mimetic action of flavonoids which is contained in I. batatas leave extract thought 
to play a role in maintaining normal blood glucose after STZ induction.

\section{Histology of the Pancreas}

Assessment of morphology of the pancreas tissue was performed by evaluating the degree of insulitis in 10 Langerhans islets for each rat at 400x magnification. Figure 1 showed the potential effect of STZ to induce insulitis and protective effect of $I$. batatas leaves extract. Diabetic rats treated with the extract had a lower grade of insulitis compared to normal and untreated ones depend on the doses (Table 2). Diabetic rats treated with $2.5 \mathrm{~g} / \mathrm{kg}$ BW extract group had better histologic patterns among untreated and treated groups significantly $(p<0.05)$. Post hoc analysis confirmed this result, Mann-Whitney $U$ test showed significant differences between each group in this study $(p<0.05)$, except diabetic rat treated 0.25 $\mathrm{g} / \mathrm{kg}$ BW extract group with treated $0.8 \mathrm{~g} / \mathrm{kg} \mathrm{BW}$ extract group $(p=0.261)$. However, we only found $18(36 \%)$ islets with a normal pattern in this group compared to $50(100 \%)$ in the normal control group.

The pancreas is a small elongated organ that lies in the upper abdomen behind the stomach. It is part of the gastrointestinal system that produces and secrets digestive enzymes into the intestine. It also acts as an endocrine organ that makes and secrets hormones into circulation to control metabolism throughout the body. The majority of the pancreas is made up of exocrine cells. The endocrine portion of pancreas (the Langerhans islet) comprises only 1-2\% of pancreatic mass. The alpha, beta, delta, and pancreatic polypeptide (PP) endocrine cells are located within the Langerhans islet. The insulin-producing cells (beta cells) account for approximately $70-80 \%$ of the total cells in the islet (Gialleonardo et al., 2012; In't Veld, 2011).

Table 2. Effect of Ipomoea batatas L leaves extract on the degree of insulitis

\begin{tabular}{|c|c|c|c|c|c|}
\hline \multirow{2}{*}{ Groups } & \multicolumn{5}{|c|}{ Grade of Insulitis n(\%) } \\
\hline & 0 & 1 & 2 & 3 & 4 \\
\hline Normal rat ${ }^{*}$ & $50(100)$ & $0(0)$ & $0(0)$ & $0(0)$ & $0(0)$ \\
\hline Diabetic rat untreated & $1(2)$ & $2(4)$ & $33(66)$ & $13(26)$ & $1(2)$ \\
\hline Diabetic rat $+0.25 \mathrm{~g} / \mathrm{kgBW}$ extract ${ }^{*}$ & $0(0)$ & $5(10)$ & $43(86)$ & $2(4)$ & $0(0)$ \\
\hline Diabetic rat $+0.8 \mathrm{~g} / \mathrm{kgBW}$ extract ${ }^{*}$ & $2(4)$ & $15(30)$ & $24(48)$ & $9(18)$ & $0(0)$ \\
\hline Diabetic rat $+2.5 \mathrm{~g} / \mathrm{kgBW}$ extract ${ }^{*}$ & $18(36)$ & $10(20)$ & $20(40)$ & $2(4)$ & $0(0)$ \\
\hline
\end{tabular}

* $p<0.05$ vs diabetic rat untreated group
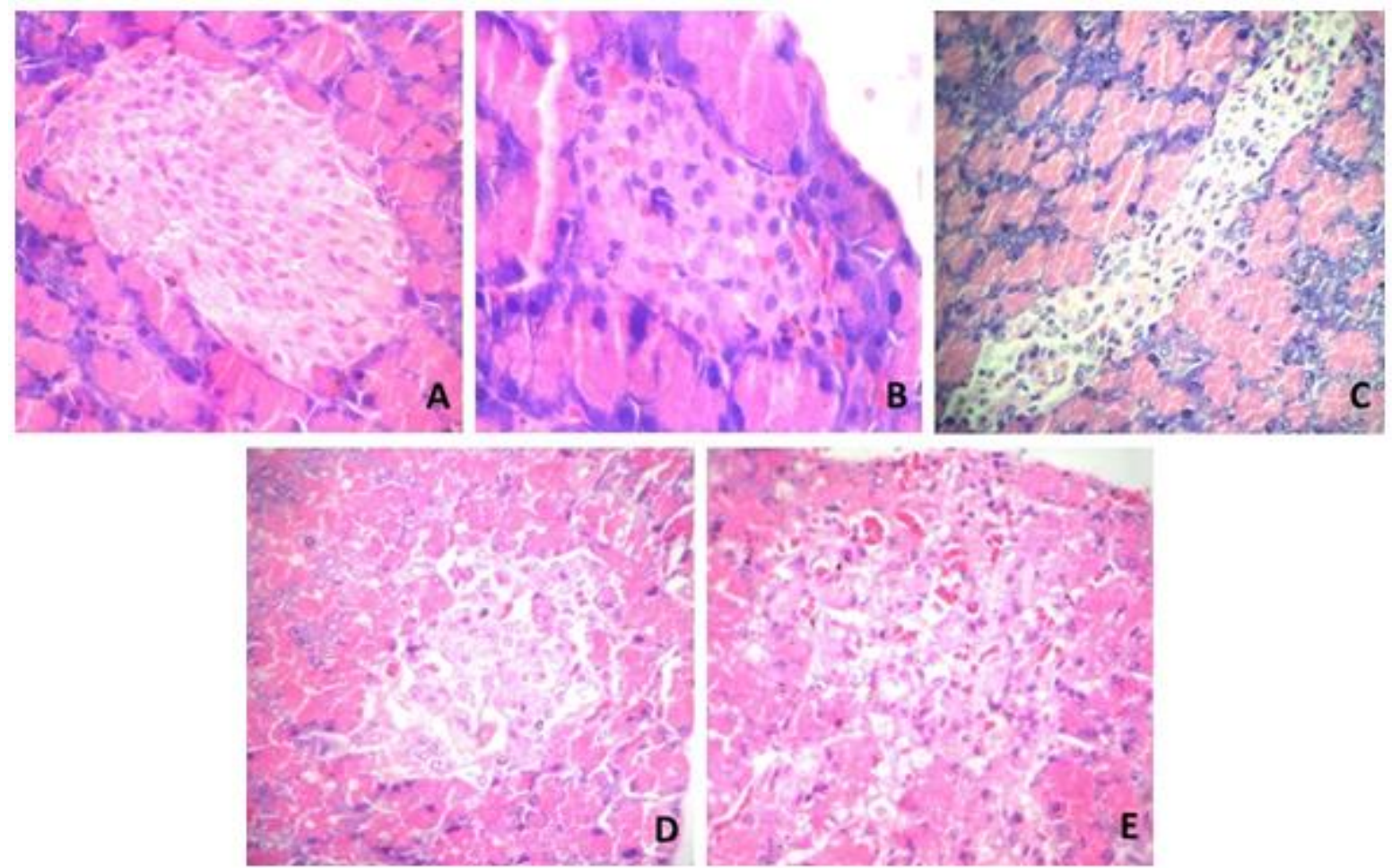

Figure 1. Grade of insulitis. A. Normal islet in normal control group showing no lymphocyte infiltration; B. Insulitis grade 1, there is minimal lymphocyte infiltration in the periphery of the islet; $\mathrm{C}$. Insulitis grade 2 , there is infiltration of lymphocyte in the periphery and within the islet; D. Insulitis grade 3, severe inflammation lead to destruction more than $50 \%$ of the islet mass; D. Insulitis grade 4 , slide section showing total necrosis of the islet (end-stage islet). (HE, 400x magnification). 
Inflammatory lesion of Langerhans islet termed insulitis has long been considered as a pathologic hallmark of TID (In't Veld, 2011). Insulitis is defined as the presence of a predominantly lymphocytic infiltration at least in three Langerhans islets. It can be peripheral insulitis or within islet parenchyma (Intra insulitis) (Campbell-Thompson et al., 2013). In the animal model, a single large dose of STZ (180-190 $\mathrm{mg} / \mathrm{kg}$ body weight) delivered intraperitoneally causes enormous beta cells necrosis within 2-3 days after administration. By contrast, injection of MLDS (35-55 $\mathrm{mg} / \mathrm{kg}$ body weight/day for 4-5 consecutive days) causes insulitis and induce sub-toxic effect on beta cells. It makes MLDS an effective method for inducing hyperglycemia and mimics TID (Chaudhry et al., 2013; Deeds et al., 2011). Our results supported those previous studies, Sprague-Dawley rats administered with MLDS intraperitoneally had various degree of insulitis.

Insulitis is a manifestation of an immunologically mediated destruction of pancreatic beta cells. T1D is defined by destruction $>75 \%$ insulin-secreting beta cells related to insulitis (In't Veld, 2011). Histological examination of the pancreas in this study showed remarkable inhibition of insulitis in treated groups. These results suggested that I batatas leave extract could prevent excessive beta cells injury by inhibiting inflammatory reaction on Langerhans islets.

Flavonoids have an important antioxidant activity, which explains their beneficial effect on diabetic therapy. The antioxidant action of flavonoids includes suppression of ROS formation, scavenging ROS, and upregulation of antioxidant defenses (Kumar \& Pandey, 2013). Anthocyanin, quercetin, and catechin have the capability to inhibit the production of TNF- $\alpha$ and nitric oxide (NO) by lipopolysaccharides from activated macrophages. Inhibition of TNF- $\alpha$ occurs post-transcription, whereas inhibition of inducible nitric oxide synthase occurs in the transcription phase. Suppression of TNF- $\alpha$ might be due to the ability of those compounds to inhibit NFkB activation (Bellik et al., 2013). Meanwhile, the biological activity of caffeic acid has been widely studied as an anti-tumor and anti-inflammatory. It can inhibit inducible nitric oxide synthase (iNOS) gene expression and then suppress NO production by macrophages (Armutcu, Akyol, Ustunsoy, \& Turan, 2015).

The active compounds of I batatas leave extract to seem to have a similar pathway in inhibiting the inflammatory process. It can be explained that phenol and flavonoids work as inhibitors of iNOS activity that suppress the production of NO. They also hinder the activation of $N F_{k B}$, a specific $B$ cell nuclei protein that acts as the primary regulator of the inflammatory response following pro-inflammatory cytokines (Liu, Zhang, Joo, \& Sun, 2017). Success in inhibiting the activation of $N F K B$ will weaken the autoimmune and inflammatory response, and inhibiting the inflammatory process in Langerhans islet (insulitis).

\section{Beta Cell Insulin Expression}

Insulin is a polypeptide hormone that regulates a wide number of physiological process that comprises gene mechanism and non-gene mechanism as well. It regulates cellular growth, cell differentiation, and metabolism of lipid, protein, and glucose. Defects in insulin secretion, action or both will lead to chronic hyperglycemia known as diabetes (Rojas et al., 2018). Previous studies found a decreasing number of insulin immunoreactive beta-cells in Langerhans islet of diabetic rats (Abunasef, Amin, \& Abdel-Hamid, 2014; Ahmadi, Karimian, Sotoudeh, Bahadori, \& Dehghani, 2010), signifying that immunohistochemical staining with anti-insulin antibody can be used to assess functioning beta-cells.

In our study, immunohistochemistry of beta-cell insulin was evaluated using the Allred score in 10 Langerhans islets for each rat at 400x magnification. Figure 2 showed that beta-cell insulin expression decreases along with increasing levels of insulitis. Diabetic rats treated with the extract had a higher score compared to untreated ones depend on the doses (Table 2). Diabetic rats treated with $2.5 \mathrm{~g} / \mathrm{kg}$ BW extract group had better scores among untreated and treated groups significantly $(p<0.05)$. Post hoc analysis showed significant differences between each group in this study $(p<0.05)$.

Destruction of beta cells in TID has been attributed to several mechanisms as follow: expression of both apoptosis stimulating fragment (Fas) and Fas ligand (Fas-L) on the surface of activated T lymphocyte and pancreatic beta cells; secretion of pro-inflammatory cytokines such as TNF- $\alpha$, IL-1 $\beta$, and IFN- $\gamma$ that induce inflammation of the Langerhans islets; and production of reactive oxygen species (ROS) such as NO by macrophages (Rojas et al., 2018). In TID animal model, STZ injection can activate ROS production, subsequently causing DNA damage. It triggers polyADP-ribosylation that causes reduction of NAD and followed by ATP depletion, resulting in beta cell death and necrosis (Szkudelski, 2001). Cellular oxidative is a critical step in beta cell destruction induced by STZ. Formation of TNF- $\alpha$, a pro-inflammatory cytokine significantly increased in STZ induced diabetic rats. It plays a role in peripheral insulin resistance, beta-cell apoptosis, and reduction of insulin secretion (Niwa ef al., 2011).

In our study, histological examination of the pancreas in diabetic rats administered with I batatas leaves extract showed remarkable inhibition of insulitis. Further, the insulin expression score of beta cells was higher in the treated groups compared to the untreated one. These results proved the potential effect of I. batatas leaf extracts to maintain beta-cell function through inhibition of inflammatory reaction in the Langerhans islet. 
Table 3. Effect of Ipomoea batatas L leaves extract on beta-cell insulin expression

\begin{tabular}{ll}
\hline \multicolumn{1}{c}{ Groups } & Allred Score \\
\hline Normal rat & $8.00 \pm 00.00^{*}$ \\
Diabetic rat untreated & $1.20 \pm 1.095$ \\
Diabetic rat $+0.25 \mathrm{~g} / \mathrm{kgBW}$ extract & $2.20 \pm 0.447^{*}$ \\
Diabetic rat $+0.8 \mathrm{~g} / \mathrm{kgBW}$ extract & $3.00 \pm 0.707^{*}$ \\
Diabetic rat $+2.5 \mathrm{~g} / \mathrm{kgBW}$ extract & $4.40 \pm 1.673^{*}$ \\
\hline
\end{tabular}

${ }^{*}: p<0.05$ vs diabetic rat untreated group

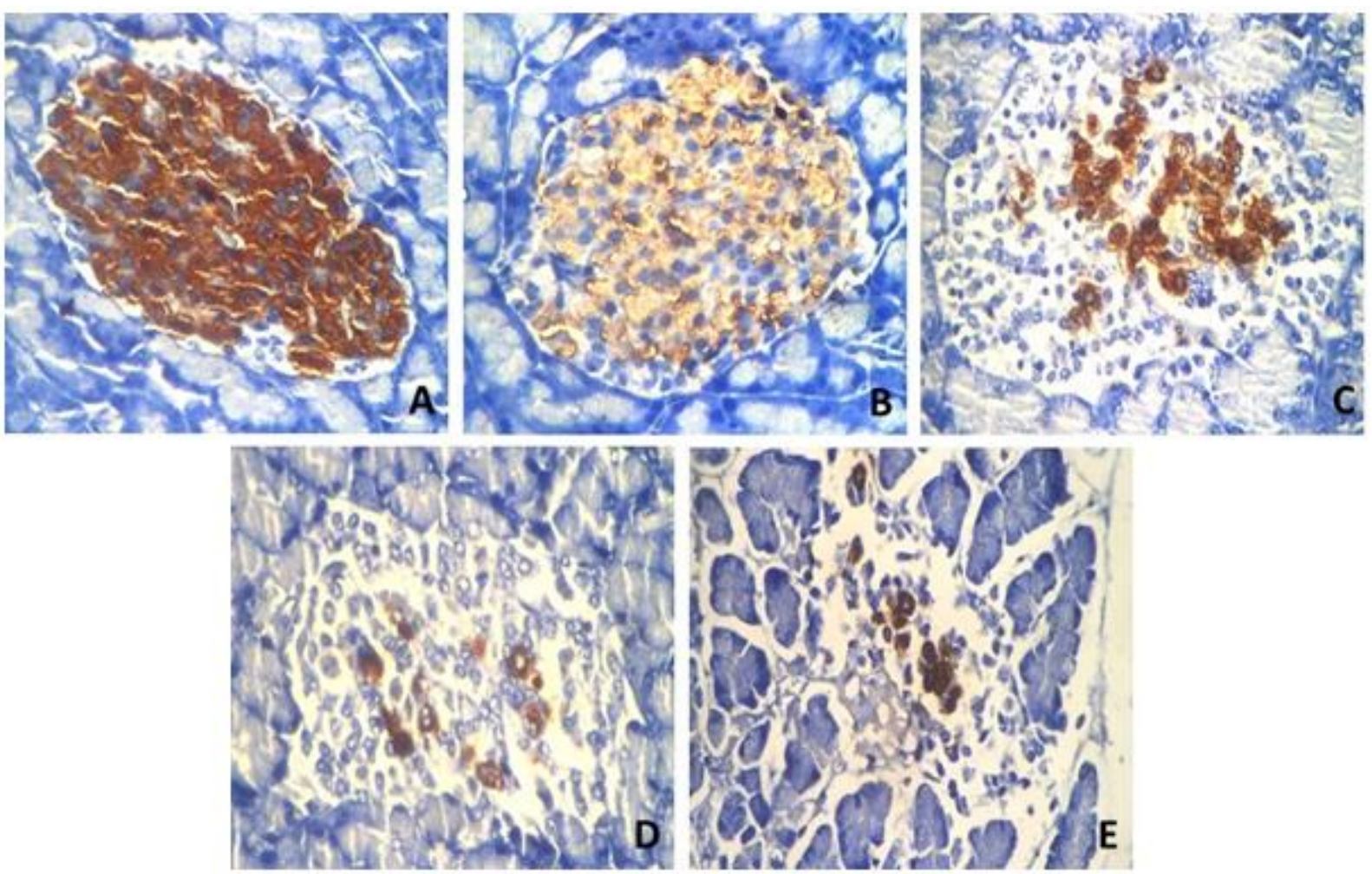

Figure 2. Beta-cell insulin expression in normal islet showing strong immunoreactivity (A), in low-grade insulitis showing a decrease of intensity with normal proportion (B), in moderate grade insulitis (C), and high-grade insulitis (D, E) showing marked decrease of immunoreactivity. (IHC, 400x magnification).

Our results support the previous study that showed anti-inflammatory, immunomodulatory and antioxidant properties of I batatas leaves extract might play an important role in removing oxidative damage caused by STZ induction (Ayeleso et al., 2016; Niwa et al., 2011). I. batatas has a potential effect in suppressing TNF- $\alpha$ level, and depressing expression of p38 mitogen-activated protein kinase (p38 MAPK), a protein kinase that involved in apoptosis induction of beta-cells, and also participates in controlling cellular responses to cytokines and stress (Niwa et al., 2011; Šrámek et al., 2016).

Hypoglycemic effects of I batatas leaves extract might work through this anti-inflammatory mechanisms and stimulation of insulin secretion. Therefore I. batatas leave extract is likely to have a protective effect on autoimmune disease such as T1D. Nevertheless, the beneficial effects of I batatas leave extract is in a dose-dependent manner. In this study, the highest dose could maintain approximately $50 \%$ of normal islets. It means that the optimum dose may not have been reached yet. Therefore, further investigation to explore the potential effect of I batatas leaf for diabetic therapy is recommended.

\section{CONCLUSIONS}

This experiment demonstrated the potential effect of Ipomoea batatas L leaves extract in suppressing insulitis and protecting pancreatic beta-cell on STZ induced diabetic rats. Therefore, this plant can be recommended as a potential source for the discovery of an alternative drug for TID therapy.

\section{REFERENCES}

Abunasef, SK., Amin, HA, \& Abdel-Hamid, GA. (2014). A histological and immunohistochemical study of beta cells in streptozotocin diabetic rats treated with caffeine. Folia Histochemica et Cytobiologia, 52(1), 42-50.

Ahmadi, S., Karimian, SM., Sotoudeh, M., Bahadori, M, \& Dehghani, GA. (2010). Pancreatic islet 
beta cell protective effect of oral vanady sulphate in streptozotocin-induced diabetic rats, an ultrastructure study. Pak J Biol Sci, 13, 1135 1140.

Allred, DC., Harvey, JM., Berardo, M, \& Clark, GM. (1998). Prognostic and predictive factors in breast cancer by immunohistochemical analysis. Mod Pathol, 11 (2), 155-168.

Armutcu, F ., Akyol, S., Ustunsoy, S , \& Turan, FF (2015). Therapeutic potential of caffeic acid phenethyl ester and its anti-inflammatory and immunomodulatory effects (Review). Experimental and Therapeutic Medicine, 9, 1582-1588.

Ayeleso, TB., Ramachela, K, \& Mukwevho, E. (2016). A review of therapeutic potentials of sweet potato: Pharmacological activities and influence of the cultivar. Trop J Pharm Res, 15(12), 2751.

Bellik, Y ., Boukraâ, L ., Alzahrani, HA., akhotmah, BA ., Abdellah, F., Hammoudi, SM, \& Ouada, MI. (2013). Molecular Mechanism Underlying AntiInflammatory and Anti-Allergic Activities of Phytochemicals: An Update. Molecules 18, 322-353.

Campbell-Thompson, ML., MA, Atkinson., AE, Butler., Chapman, NM., Frisk, G., Gianani, R, . . . In't Veld, PA. (2013). The diagnosis of insulitis in human type 1 diabetes. Diabetologia 56, 2541 2543.

Carvalho, IS., Cavaco, T., Carvalho, LM, \& Duque, P. (2010). Effect of photoperiod on flavonoid pathway activity in sweet potato (Ipomoea batatas (L.) Lam.) leaves. Food Chem, 118, 384-390.

Cazarolli, LH., Zanatta, L., Alberton, EH., Figueiredo, MSRB., Folador, P., Damazio, RG, . . . Silva, FRMB. (2008). Flavonoids: Cellular and Molecular Mechanism of Action in Glucose Homeostasis. Mini-Reviews in Medicinal Chemistry, 8, 1032-1038.

Chaudhry, ZZ., Morris, DL., Moss, DR., Sims, EK., Chiong, Y., Kono, T, \& Molina, CE. (2013). Studies of streptozotocin-induced insulitis and diabetes. Laboratory Animals, 47(4), 257-265.

Choi, HG., Tran, PT., Lee, JH., Min, BS, \& Kim, JA. (2018). Anti-inflammatory activity of caffeic acid derivatives isolated from the roots of Salvia miltiorrhiza Bunge. Archives of Pharmacal Research, 41(1), 64-70.

Deeds, MC., Anderson, JM., Armstrong, AS., Gastineau, DA., Hiddinga, HJ., Jahangir, A, . . . Kudva, YC. (2011). Single dose streptozotocininduced diabetes: considerations for study design in islet transplantation models. Lab Anim, 45, 131-140.

Ghasemzadeh, A., Omidvar, V, \& Jaafar, HZE. (2012). Polyphenolic content and their antioxidant activity in leaf extract of sweet potato (Ipomoea batatas) J. Med. Plants Res, 6(15), 2971-2976.

Gialleonardo, VD ., Vries, EFJ ., Girolamo, MD ., Quintero, AM., Dierckx, RAJO , \& Signore, A. (2012). Imaging of Beta Cell Mass and Insulitis in Insulin-Dependent (Type 1) Diabetes Mellitus. Endocrine Reviews 33, 892-919.

Goud, BJ., Dwarakanath, V, \& Swamy, BKC. (2015). Streptozotocin - A Diabetogenic Agent in Animal Models. lippr.Human, 3(1), 253-269.

Hue, SM ., Boyce, AN, \& Somasundram, C. (2012). Antioxidant activity, phenolic and flavonoid contents in the leaves of different varieties of sweet potato (Ipomoea batatas) AJCS 6(3), 375 380.

ljaola, T O., Osunkiyesi, A A., Taiwo, A A., Oseni, O A., Lanrelyanda, Y A., Ajayi, J O, \& Oyede, R T. (2014). Antidiabetic Effect of Ipomoea Batatas in Normal and Alloxan-Induced Diabetic Rats. IOSR Journal of Applied Chemistry (IOSR-JAC), 7(5), 16-25.

In't Veld, P. (2011). Insulitis in human type 1 diabetes - The quest for an elusive lesion. Islets, 3(4), $131-138$.

Kawasaki, E. (2014). Type 1 Diabetes and Autoimmunity. Clinical Pediatric Endocrinology 23(4), 99-105.

Koncic, MZ., Petlevski, R, \& Kalođera, Z. (2013). Antioxidant Activity of Ipomoea batatas L. Lam. Leaf Grown in Continental Croatia and Its Effect on Glutathione Level in Glucose-Induced Oxidative Stress. International Journal of Food Properties, 16(5), 964-973.

Kumar, S, \& Pandey, AK. (2013). Chemistry and Biological Activities of Flavonoids: An Overview. The Scientific World Journal. doi: http://dx.doi.org/10.1155/2013/162750

Lien, DN., Phuc, DV., Lien, PQ., Trang, NT., Kien, TT., Lien, TTP, \& Tien, KD. (2011). Effect of Sweet potato (Ipomoea batatas (L.) Lam) leaf extract on hypoglycaemia, blood insulin secretion, and key carbohydrate metabolic enzymes in experimentally obese and STZ-induced diabetic mice. VNU Journal of Science, Natural Sciences and Technology 27, 118-124.

Liu, T ., Zhang, L ., Joo, D, \& Sun, SC. (2017). NF-kB signaling in inflammation. Signal Transduct Target Ther, 2, 17023 . doi: http://dx.doi.org/10.1038/sigtrans.2017.23

Majid, M., Nasir, B., Zahra, SS., MR, Khan., Mirzam, B, \& Haq, I. (2018). Ipomoea batatas L. Lam. ameliorates acute and chronic inflammations by suppressing inflammatory mediators, a comprehensive exploration using in vitro and in vivo models. BMC Complementary and Alternative Medicine, 18(216). doi: http://dx.doi.org/10.1186/s12906-018-2279-5

Martin, AP., Alexander-Bret, JM., Canasto-Chibuque, C., Garin, A., Bromberg, JS., Fremont, DH, \& 
Lira, SA. (2007). The Chemokine Binding Protein M3 Prevents Diabetes Induced by Multiple Low Doses of Streptozotocin. J Immunol, 178, 4623-4631.

Mbayei-Nwaoha, I E, \& Emejulu, V N. (2013). Evaluation of Phytochemical Composition and Antimicrobial Activity of Sweet Potato (Ipomoea batatas) Leaf. Pak. J. Nutr, 12(6), 575-586.

Niwa, A., Tajiri, T, \& Higashino, H. (2011). Ipomoea batatas and Agarics blazei ameliorate diabetic disorders with therapeutic antioxidant potential in streptozotocin-induced diabetic rats. J. Clin. Biochem. Nutr, 48(3), 194-202.

Pournaghi, P., Sadrkhanlou, RA., Hasanzadeh, S, \& Foroughi, A. (2012). An investigation on body weights, blood glucose levels and pituitarygonadal axis hormones in diabetic and metformin-treated diabetic female rats. Veterinary Research Forum, 3(2), 79-84.

Rafiu, AA, \& Luka, CD. (2018). Effects of Aqueous Extract of Ipomoea batatas Leaf on Blood Glucose, Kidney Functions And Hematological Parameters Of Streptozotocin-Induced Diabetic Rats. J Res Diabetes Metab, 4(1), 4-9.

Rojas, J., Bermudez, V., Palmar, J., Martínez, MS., Olivar, LC., Nava, M, . . . Velasco, M. (2018). Pancreatic Beta Cell Death: Novel Potential Mechanisms in Diabetes Therapy. Journal of Diabetes Research. doi: http://dx.doi.org/10.1155/2018/9601801

Rosol, TJ., DeLellis, RA., Harvey, PW, \& Sutcliffe, C. (2013). Endocrine System Haschek and Rousseaux's Handbook of Toxicologic Pathology (Third Edition) (Vol. III, pp. 2391-2492): Academic Press.

Sarian, MN., Ahmed, QU., Mat So'ad, SZ., Alhassan, AM., Murugesu, S., Perumal, V, . . . Latip, J. (2017). Antioxidant and Antidiabetic Effects of Flavonoids: A Structure-Activity Relationship Based Study. BioMed Research International.

Shaw, JE., Sicree, RA , \& Zimmet, PZ. (2010). Global estimates of the prevalence of diabetes for 2010 and 2030. Diabetes Research and Clinical Practice, 87, 4-14.
Sidoryk, K., Jaromin, A ., Filipczak, N., Cmoch, P , \& Cybulski, M. (2018). Synthesis and Antioxidant Activity of Caffeic Acid Derivatives. Molecules 23(9), $2199 . \quad$ doi: http://dx.doi.org/10.3390/molecules23092199

Soares, JMD ., Leal, AEBP ., Silva, JC ., Almeida, JRGS, \& Oliveira, HP. (2017). Influence of Flavonoids on Mechanism of Modulation of Insulin Secretion. Pharmacogn Mag, 13(52), 639-646.

Šrámek, J., Němcová-Fürstová, V., Balušíková, K., Daniel, P., Jelínek, M ., James, RF, \& Kovář, J. (2016). p38 MAPK Is Activated but Does Not Play a Key Role during Apoptosis Induction by Saturated Fatty Acid in Human Pancreatic $\beta$ Cells. Int J Mol Sci, 17(159). doi: http://dx.doi.org/10.3390/ijms 17020159

Sun, H., Mu, T., Xi, L., Zhang, M, \& Chen, J. (2014). Sweet potato (Ipomoea batatas L.) leaves as nutritional and functional foods. Food Chem, 156, 380-389.

Szkudelski, T. (2001). The Mechanism of Alloxan and Streptozotocin Action in B Cells of the Rat Pancreas. Physiological Research, 50/536546).

Thulesen, J., Cathrine, O., Jensd, JH, \& Steel, SP. (1997). Short term insulin treatment prevents the diabetogenic action of streptozotocin in rats. Endocrinol, 138(1), 62-68.

Tyka, K., Jörns, A., Turatsinze, JV., Eizirik, DL., Lenzen, S, \& Gurgul-Convey, E. (2019). MCPIP1 regulates the sensitivity of pancreatic beta-cells to cytokine toxicity. Cell Death \& Disease, 10(1), 29. doi: http://dx.doi.org/10.1038/s41419018-1268-4

Weir, GC, \& Bonner-Weir, S. (2013). Islet beta cell mass in diabetes and how it relates to function, birth, and death. Ann N Y Acad Sci, 1281, 92105.

Wu, J, \& Yan, LJ. (2015). Streptozotocin-induced type 1 diabetes in rodents as a model for studying mitochondrial mechanisms of diabetic $\beta$ cell glucotoxicity. Diabetes, Metabolic Syndrome and Obesity: Targets and Therapy, 8, 181-188. 